\title{
PENGEMBANGAN GAME EDUKATIF BERBASIS ANDROID SEBAGAI MEDIA PEMBELAJARAN AKUNTANSI PADA MATERI JURNAL PENYESUAIAN PERUSAHAN JASA
}

\author{
DEVELOPING ANDROID BASED EDUCATIONAL GAME AS A MEANS OF \\ ACCOUNTING LEARNING ON SERVICE COMPANY ADJUSTING JOURNAL \\ MATERIAL
}

Oleh: Ditto Rahmawan Putra

Prodi Pendidikan Akuntansi Universitas Negeri Yogyakarta dittorahmawanputra@gmail.com

Mahendra Adhi Nugroho

Staf Pengajar Jurusan Pendidikan Akuntansi Universitas Negeri Yogyakarta

\begin{abstract}
Abstrak
Penelitian ini bertujuan untuk Mengembangkan game edukatif berbasis android; mengetahui kelayakan game edukatif berbasis android sebagai media pembelajaran; mengetahui penilaian siswa terhadap media pembelajaran. Penelitian ini merupakan jenis penelitian dan pengembangan dengan mengikuti model pengembangan ADDIE (Analysis, Design, Development, Implementation, Evaluation) yaitu tahap analisis, desain, pengembangan, implementasi, dan evaluasi, namun hanya dilaksanakan hingga tahap keempat, yaitu implementasi. Hasil penelitian menunjukkan bahwa tingkat kelayakan game edukatif berbasis android sebagai media pembelajaran akuntansi berdasarkan penilaian : 1) Ahli Materi diperoleh rata-rata skor 4,87 yang termasuk dalam kategori sangat layak, 2) Ahli Media diperoleh ratarata skor 4,33 yang termasuk dalam kategori sangat layak, 3) Praktisi Pembelajaran Akuntansi diperoleh rata-rata skor 4,75 yang termasuk dalam kategori sangat layak, 4) Penilaian siswa kelas XI IPS 3 SMA Negeri 1 Imogiri diperoleh skor 4,19 yang termasuk dalam kategori Layak. Dengan demikian game edukatif "Asah Akuntansi" berbasis android yang dikembangkan sangat layak digunakan sebagai media pembelajaran akuntansi.
\end{abstract}

Kata kunci: Media Pembelajaran, Akuntansi, Game Edukatif, Android, SMA, Jurnal Penyesuaian.

\begin{abstract}
The aims of this research are; to develop android based educational game as a means of accounting; to learn the feasibility of the android based educational game; to know students' evaluation of the android based educational game. The approach of this research is Research and Development that take the ADDIE (Analysis, Design, Development, Implementation, and Evaluation) model, but it is only conducted up to the fourth stages, which is Implementation. The results show that the development of the android based educational game as means of accounting learning based on experts evaluation are: 1) Subject Experts gave 4,87 average score, which goes into very feasible category, 2) Media Experts gave 4,33 average score, which goes into very feasible category, 3) Accounting Learning Practitioners gave 4,75 average score which goes into very feasible category, 4) Student Assesment shows of 4,19 average score, which goes into feasible category. This, android based educational game developed is very feasible as means of accounting learning.
\end{abstract}

Keywords: Learning Media, Accounting, Educational Game, Android, Senior High School, Adjusting Journal. 


\section{PENDAHULUAN}

Pendidikan merupakan proses pembelajaran untuk mengembangkan potensi, kecakapan, dan karakteristik pribadi peserta didik melalui usaha sadar dan terencana. Ketiga hal itu merupakan modal utama untuk meningkatkan kualitas sumber daya manusia suatu bangsa (SDM). Kualitas SDM merupakan ukuran kemajuan suatu negara. Dengan adanya SDM yang berkualitas dan berpendidikan akan tercipta pembangunan nasional. Semakin banyak orang yang berpendidikan dan berkualitas maka semakin mudah untuk membuat negaranya lebih maju.

Pendidikan yang dapat menghasilkan SDM berkualitas membutuhkan suatu proses pembelajaran. Proses pembelajaran terjadi karena adanya interaksi antara seseorang dengan lingkungannya. Ketercapaian suatu proses pembelajaran ditunjukkan dengan adanya perubahan tingkah laku yang lebih baik dimana menyangkut perubahan, pengetahuan (kognitif), ketrampilan (psikomotor), maupun yang menyangkut nilai dan sikap (afektif). Ketercapaian perubahan-perubahan tersebut dipengaruhi oleh beberapa faktor antara lain, pendidik, peserta didik, lingkungan, metode pembelajaran, serta media pembelajaran.

Media pembelajaran merupakan alat bantu guru dalam proses kegiatan pembelajaran. Dengan demikian tujuannya untuk mempermudah guru dalam menyampaikan materi kepada siswa. Selain itu, media pembelajaran membantu siswa untuk menyiapkan dan menerima materi karena dapat digunakan siswa secara mandiri di rumah. Media pembelajaran harus dikemas secara baik dan menimbulkan daya tarik agar siswa menjadi betah untuk belajar. Kurang variatifnya media bukan semata-mata kesalahan guru, namun karena waktu pembelajaran akuntansi yang sedikit, kondisi sekolah, karakter siswa, dan kurang mengoptimakan perkembangan teknologi.

Perkembangan teknologi semakin hari semakin meningkat. Perkembangan ini memberikan berbagai kemudahan kepada manusia untuk menjalankan segala aktivitas atau kegiatan sehari-hari, contoh dari perkembangan teknologi adalah telepon genggam. Teknologi komunikasi ini berkembang dengan sangat pesat karena harganya yang cukup ekonomis dan mudah didapatkan. Saat ini setiap orang dari berbagai lapisan memiliki telepon genggam mulai dari kalangan pemerintah sampai daerah perbatasan. Teknologi ini sangat membantu dan bermanfaat bagi kehidupan manusia, misalnya untuk berkomunikasi dengan saudara yang jaraknya jauh untuk memberitahukan kondisinya. Namun, tidak semua masyarakat Indonesia mampu memanfaatkan teknologi ini dengan baik dan tepat sasaran, dalam dunia pendidikan misalnya banyak siswa yang menggunakan telepon genggam selama kegiatan belajar mengajar (KBM) berlangsung. Apalagi generasi telepon genggam yang tidak hanya digunakan untuk mengirim pesan singkat saja, tetapi untuk mengakses internet terutama jejaring sosial, video call, dan bermain game. Dengan demikian, siswa akan lebih suka menggunakan telepon genggamnya untuk bersenang-senang daripada belajar. Teknologi yang digunakan tidak pada tempatnya akan menjadi momok mengerikan khususnya dalam bidang pendidikan.

Smartphone atau telepon pintar adalah perangkat telepon genggam handphone yang bisa digunakan untuk berkomunikasi dasar (mengirim pesan singkat dan telepon), serta di dalamnya terdapat fungsi PDA (Personal Digital Assistant) dan dapat bekerja layaknya sebuah computer mini. Generasi smartphone ini merupakan dampak dari perkembangan teknologi yang melaju pesat. Menurut lembaga riset Roy Morgan, periode maret 2012-2013 kepemilikan smartphone di Indonesia naik dua kali lipat, dari $12 \%$ menjadi $24 \%$ dari total populasi di Indonesia. Sementara itu, pengguna telepon seluler naik $10 \%$ mencapai $84 \%$ dari total populasi Indonesia pada maret 2013. Tutut (2013) mengemukakan bahwa penggunaan smartphone atau telepon pintar di indonesia 
pada kuartal ke-II tahun 2013 hampir menembus 15 juta unit dan mayoritas pengguna berasal dari kalangan remaja dengan kisaran umur 15-18 tahun. Kemudian Menurut Lembaga Riset digital marketing emarketer memperkirakan pada 2018 jumlah pengguna aktif smartphone di Indonesia lebih dari 100 juta orang. Smartphone dapat berkembang pesat dengan harga yang dapat dijangkau oleh berbagai kalangan dengan specification dan type smartphone yang beranekaragam. Pesatnya perkembangan smartphone bisa menjadi tantangan dan peluang khususnya di dunia pendidikan. Tantangan tersebut dilihat dari banyaknya kasus siswa menggunakan telepon genggam di kelas seperti yang sudah disebutkan di bagian sebelumnya yaitu untuk mengirim pesan singkat, bermain game, serta adanya siswa yang menyimpan video-video tidak pantas untuk dilihat oleh remaja. Sedangkan peluangnya adalah pemanfaatan dalam dunia pendidikan yaitu lewat pengembangan media pembelajaran yang inovatif, kreatif, dan interaktif.

SMA Negeri 1 Imogiri merupakan salah satu sekolah menengah atas yang sudah menerapkan Kurikulum Tingkat Satuan Pendidikan. SMA Negeri 1 Imogiri berlokasi di di Jln. Imogiri Timur Km 14 wukirsari, Imogiri, Bantul. SMA Negeri 1 Imogiri juga didukung oleh tenaga pengajar yang berjumlah 41 orang dengan jumlah kelas sebanyak 21 kelas yang terdiri dari kelas X, XI, dan kelas XII.

Berdasarkan Observasi secara langsung siswa kelas XI IPS 3 di SMA N 1 Imogiri sekitar $92 \%$ atau 25 siswa dari 27 siswa merupakan pengguna smartphone, yaitu Android. Sedangkan sisanya telepon genggam biasa. Alasan terbanyak menggunakan smartphone adalah mengikuti life style, fitur-fitur yang ditawarkan sangatlah menarik, serta kemudahan dalam mengakses internet. Dari 27 siswa mengatakan selalu menggunakan untuk bermain games, memutar musik, mengakses jejaring sosial, dan chat dengan temantemannya. Sedangkan aplikasi yang berhubungan dengan dunia pendidikan di perangkat smartphone mereka masih terbatas pada penggunaan browser untuk mengakses google, dan kamus elektronik. Di SMA N 1 Imogiri belum ada media pembelajaran yang memanfaatkan smartphone. Para siswa masih banyak yang menggunakan laptop atau bahkan masih ada yang menggunakan buku manual untuk menunjang pembelajaran di sekolah. Dengan menggunakan laptop sebagai media pembelajaran akan menyulitkan siswa membawa perangkat tersebut karena berat dan terkesan repot. Guru pun masih menggunakan metode konvensional dalam mengajar sehingga peserta didik merasa bosan ketika melakukan kegiatan pembelajaran. Tenaga pendidikan di sekolah ini masih menggunakan metode ceramah khususnya dalam pembelajaran akuntansi sehingga siswa kurang tertarik dan lebih memilih untuk melakukan hal-hal lain seperti berdiskusi dengan temannya dan sibuk dengan gadgetnya masing-masing.

Akuntansi di SMA merupakan bagian dari kompetensi lulusan mata pelajaran ekonomi berdasarkan Permendiknas No. 23 Tahun 2008 mengenai Standar Kompetensi Lulusan. Menurut pengamatan/Observasi di SMAN 1 Imogiri Bantul, sekitar $85 \%$ siswa atau 23 Siswa dari 27 siswa menyatakan akuntansi dianggap sulit untuk dipahami dan dimengerti karena memerlukan pemahaman konsep yang baik dan kemampuan berhitung yang baik pula, sedangkan mayoritas mata pelajaran pada jurusan IPS berupa hafalan. Alokasi jam pelajaran yang disediakan untuk proses pembelajaran di kelas yang minim yaitu satu minggu 4 jam pelajaran membuat kurang optimal untuk memberi pemahaman secara mewadahi kepada siswa, serta sebagian besar handphone yang digunakan oleh siswa ialah smartphone dengan spesifikasi yang sudah memadai untuk dioperasikan dengan suatu aplikasi yang bermanfaat untuk proses pembelajaran.

Melihat fenomena di atas, maka tercipta sebuah ide untuk membuat media pembelajaran akuntansi yang inovatif, kreatif, interaktif dan dapat digunakan 
dimana saja dan kapan saja. Salah satunya adalah pengembangan media game edukasi berbasis Android. Game adalah sebuah permainan yang berfungsi sebagai warming up (pemanasan), penghilang kejenuhan dalam materi yang melelahkan, mensupport peserta mentoring agar terlibat lebih aktif dan memberi respon (Eko Susanto, 2009: 19). Hal ini telah mengungkapkan bahwa game (permainan) selalu menarik untuk diikuti dan lebih mudah untuk dipahami dengan bantuan gambar kartun yang terdapat di dalamnya. Kartun adalah penggambaran dalam bentuk lukisan atau karikatur tentang orang, gagasan, atau situasi yang didesain untuk mempengaruhi opini masyarakat (Nana Sudjana dan Ahmad Rivai, 2010: 58).

Sistem operasi yang akan digunakan adalah Android karena penggunanya merupakan yang terbesar dibandingkan sistem operasi yang lainnya seperti Blackberry OS dan iOS (iPhone Operating System) yang menguasai antara 60\%- $70 \%$ pangsa pasar smartphone sedangkan Blackberry hanya $30 \%$. Tutut (2013) mengatakan bahwa berdasarkan hasil riset Ericsson Lab pada 2011 hingga awal 2012 kepada 6.600 responden di seluruh Indonesia, pertumbuhan penggunaan smartphone di perkotaan naik dari $8 \%$ pada 2011 menjadi $22 \%$ di 2012. Hal yang mengejutkan, di pedesaan angka penggunanya juga naik dari $5 \%$ menjadi $21 \%$. Mayoritas pemakai Android pada usia SMA atau remaja. Selain itu berdasarkan hasil observasi di SMA N 1 Imogiri bantul, pengguna smartphone terbanyak siswa adalah Android yaitu $92 \%$ atau 25 siswa dari 27 siswa, sedangkan sisanya merupakan pengguna telepon genggam biasa. Android merupakan sistem operasi open source yang artinya gratis dan bebas digunakan untuk para pengembang aplikasi, hal ini sangat memudahkan para developer atau pengembang aplikasi Android atau pengembang aplikasi. Android untuk membuat berbagai jenis aplikasi Android sesuai kehendaknya. Pengguna juga sangat dimudahkan, karena kemudahan dalam mendapatkan aplikasi. Melalui Play Store, pengguna dapat mengunduh berbagai macam aplikasi dengan gratis ataupun berbayar tergantung dari developer/pembuatnya. Selain itu juga bisa berbagi melalui perangkat transfer data antar telepon (Bluetooth).

Materi Jurnal Penyesuaian Siklus akuntansi perusahaaan jasa sering dianggap sulit oleh siswa, Jurnal Penyesuaian merupakan materi yang membutuhkan pemahaman yang lebih kompleks dibandingkan materi lainnya. Dalam penyampaian materi, pendidik masih menggunakan metode konvensional, dan peserta didik sudah merasa bosan akan hal tersebut. Pelajaran akuntansi dibutuhkan kemampuan untuk berkonsentrasi. Kemampuan tersebut bisa muncul dikarenakan kesenangan, maka dari itu pendidik harus membawa peserta didik menuju suasana yang menyenangkan dan peserta didik bisa fokus pada materi yang disampaikan oleh pendidik. Oleh karena itu, peneliti mencoba memberikan solusi dengan membuat game edukatif dengan berbasis Android sebagai media pembelajaran.

Berdasarkan uraian tersebut, peneliti tertarik melakukan penelitian dengan judul "Pengembangan Game Edukatif Berbasis Android Sebagai Media Pembelajaran Akuntansi di Kelas XI IPS SMA Negeri 1 Imogiri pada Materi Jurnal Penyesuaian Perusahaan Jasa".

\section{METODE PENELITIAN \\ Jenis Penelitian}

Penelitian ini merupakan jenis penelitian dan pengembangan (Research and Development).

\section{Waktu dan Tempat Penelitian}

Peneliti mengambil tempat penelitian di SMA Negeri 1 Imogiri yang beralamat di Jln. Imogiri Timur $\mathrm{Km} 14$ wukirsari, Imogiri, Bantul. Penelitian ini dilaksanakan secara bertahap dalam waktu bulan Januari 2016 Sampai Maret 2016 yang meliputi tahap perencanaan, penelitian, dan pelaporan. 


\section{Target/Subjek Penelitian}

Subjek penelitian ini adalah seorang ahli media, seorang ahli materi, seorang praktisi pembelajaran akuntansi, dan 27 siswa Kelas XI IPS 3 SMA N 1 Imogiri.

\section{Prosedur}

Pada penelitian ini, peneliti menggunakan model pengembangan ADDIE. Menurut Dick dan Carry (1996) dalam Endang Mulyatiningsih (2012: 200202) ada lima tahapan dalam model ADDIE (analysis, design, development, implementation, evaluation). Pada penelitian ini peneliti memodifikasi model pengembangan dengan membatasi hanya sampai tahap implementasi. Tahapantahapan tersebut antara lain:

a. Tahap Analisis (Analysis)

1) Analisis Kebutuhan Siswa

Analisis kebutuhan siswa yang meliputi permasalahan dan karakteristik siswa serta perangkat keras (hardware) dan perangkat lunak (software).

2) Analisis Kompetensi dan Instruksional Meliputi analisis terhadap Standar Kompetensi (SK) dan Kompetensi Dasar (KD) apa yang akan dimuat dalam media ini kemudian dijabarkan ke dalam indikator pembelajaran yang memungkinkan untuk disajikan dalam bentuk game edukatif.

b. Tahap Desain (Design)

Berdasarkan hasil analisis, selanjutnya dilakukan tahap desain atau perancangan produk yang meliputi tiga tahap berikut:

1) Perancangan flowchart

Merupakan bagan yang terdiri dari simbol-simbol tertentu yang menunjukkan langkah-langkah suatu prosedur atau program.

2) Perancangan storyboard

Pembuatan suatu media dalam hal ini adalah game edukatif diawali dengan membuat storyboard sehingga akan dapat dilihat rancangannya.

3) Penyusunan teks materi, soal, dan jawaban

Seluruh materi yang akan dimuat dalam media dibuat dalam format .html (hypertext markup language) menggunakan program Notepad ++. Pembahasan jawaban yang akan dimuat dibuat dalam bentuk gambar dengan format .png dengan menggunakan program corelDRAW Graphicst Suite X7. Sedangkan untuk soal langsung dimasukkan ke dalam java.

4) Pembuatan dan pengumpulan background, gambar, dan tomboltombol

Background, gambar, dan tombol-tombol dibuat dalam format gambar.png dengan menggunakan corelDRAW Graphicst suite X7.

c. Tahap Pengembangan (Development) Pada tahap pegembangan ini, kegiatan yang dilakukan adalah:

1) Pembuatan Media

Pembuatan media menggunakan Android Studio. Seluruh komponen yang telah dipersiapkan pada tahap desain dirangkai menjadi satu kesatuan media yang utuh sesuai dengan desain yang telah dirancang. Ada 4 kegiatan dalam pembuatan media yaitu pembuatan antarmuka, pengkodean (coding), pengujian (testing), dan deploying.

2) Validasi I

pada tahap ini media awal divalidasi oleh satu ahli media (dosen) dan satu ahli materi (dosen). Hasilnya berupa saran, komentar, dan masukan yang dapat digunakan sebagai dasar untuk melakukan revisi I terhadap media yang dikembangkan. 
3) Revisi I

pada tahap ini media direvisi berdasarkan masukan dan saran yang diberikan oleh ahli materi (dosen) dan ahli media (dosen)

4) Validasi Tahap II

Pada tahap ini media divalidasi oleh praktisi pembelajaran Akuntansi yaitu guru Akuntansi SMA Menggunakan instrument yang telah disusun.

5) Revisi Tahap II

Pada tahap ini media direvisi kembali berdasarkan masukan dan saran yang diberikan praktisi pembelajaran akuntansi yang dalam hal ini adalah sebagai ahli materi. Media awal direvisi pada tahap ini selanjutnya digunakan pada tahap implementasi kepada siswa.

d. Tahap Implementasi (Implementation) Meliputi:

1) Uji coba lapangan

Pada tahap ini media diujicobakan kepada 27 siswa kelas XI IPS 3 SMA Negeri 1 Imogiri. Pada tahap ini juga dibagikan angket untuk mengetahui penilaian siswa mengenai media yang telah dibuat.

2) Revisi tahap III (jika diperlukan)

Dalam revisi ini akan mempertimbangkan masukan dan saran dari validator sebelumnya agar tidak bertentangan dengan perbaikan-perbaikan sebelumnya.

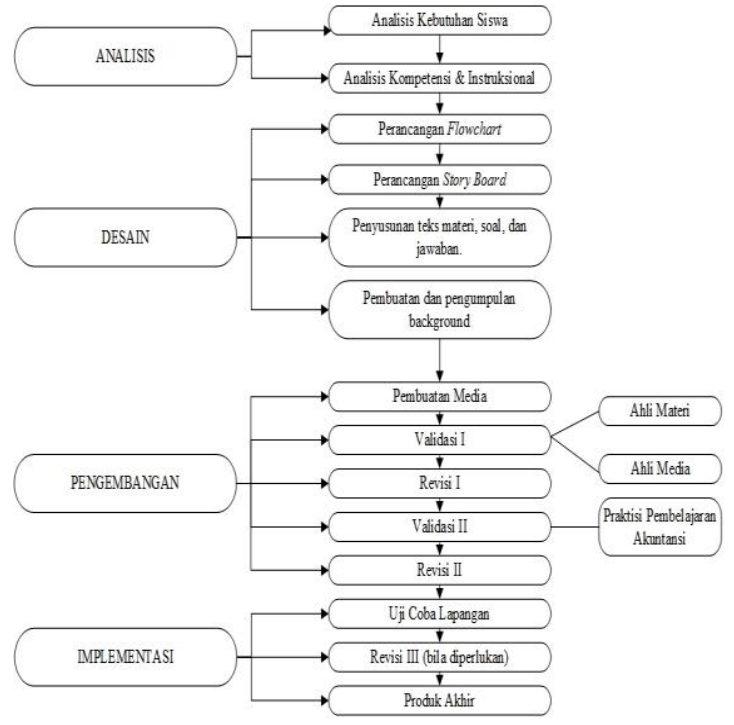

Gambar 1. Bagan Prosedur Pengembangan

Data, Instrumen, dan Teknik Pengumpulan

a. Data

Data yang dikumpulkan dalam penelitian ini mencakup data kualitatif dan kuantitatif, yaitu:

1) Data kualitatif merupakan data tentang proses pengembangan media pembelajaran berupa kritik dan saran dari para ahli materi dan ahli media.

2) Data kuantitatif merupakan data pokok dalam penelitian yang berupa data penilaian tentang media pembelajaran ular tangga dari ahli materi, ahli media, dan siswa.

Instrumen pengumpulan data yang digunakan dalam penelitian ini adalah kuesioner (angket). Menurut Sugiyono (2013: 142) angket merupakan teknik pengumpulan data yang dilakukan dengan cara memberi seperangkat pertanyaan atau pernyataan tertulis kepada responden untuk dijawab.

\section{b. Teknik Analisis Data}

Data yang diperoleh dari ahli materi, ahli media, guru dan uji coba lapangan melalui lembar angket kemudian dianalisis menggunakan teknik analisis deskriptif kualitatif dan kuantitatif. Teknik analisis deskriptif kualitatif 
digunakan untuk mengolah data berbentuk kata-kata dari hasil validasi ahli materi), ahli media, guru dan siswa. Teknik analisis deskriptif kuantitatif digunakan untuk mengolah data berbentuk angka (skor) yang diperoleh melalui angket.

1) Analisis Data Penilaian Kelayakan Media Pembelajaran

a) Mengubah penilaian kualitatif menjadi kuantitatif dengan ketentuan:

Tabel 1. Aturan Pemberian Skor Validasi

\begin{tabular}{|l|c|}
\hline \multicolumn{1}{|c|}{ Klasifikasi } & Skor \\
\hline Sangat Setuju & 5 \\
\hline Setuju & 4 \\
\hline Netral & 3 \\
\hline Tidak Setuju & 2 \\
\hline Sangat Tidak & 1 \\
\hline
\end{tabular}

b) Menghitung nilai rerata skor tiap indikator

$$
\overline{\mathrm{X}}=\frac{\sum \mathrm{X}}{\mathrm{n}}
$$

Keterangan:

$\overline{\mathrm{X}}=$ rerata skor

$\sum X=$ jumlah total skor tiap aspek

$\mathrm{n} \quad=$ jumlah item

(Eko Putro Widoyoko, 2011: 237)

c) Menjumlahkan rerata skor tiap aspek d) Menginterpretasikan rerata skor ke rumus konversi skor skala lima

Tabel 2. Pedoman Konversi Skor

\begin{tabular}{|c|c|c|}
\hline Kategori & Rumus & Rentang \\
\hline Sangat & $\mathrm{X}>\overline{\mathrm{X}} \mathrm{i}+1,80 \mathrm{SBi}$ & $X>4,20$ \\
\hline Layak & $\begin{array}{l}\overline{\mathrm{X}} \mathrm{i}+0,60 \mathrm{SBi}<X \\
\leq \overline{\mathrm{X}} \mathrm{i}+1,80 \mathrm{SBi}\end{array}$ & $\begin{array}{l}3,40<X \\
\leq 4,20\end{array}$ \\
\hline Cukup & $\begin{array}{l}\overline{\mathrm{X}} \mathrm{i}-0,60 \mathrm{SBi}<X \\
\leq \overline{\mathrm{X}} \mathrm{i}+0,60 \mathrm{SBi}\end{array}$ & $\begin{array}{l}2,60<X \\
\leq 3,40\end{array}$ \\
\hline $\begin{array}{l}\text { Kurang } \\
\text { Layak }\end{array}$ & $\begin{array}{l}\overline{\mathrm{X}} \mathrm{i}-1,80 \mathrm{SBi}<X \\
\leq \overline{\mathrm{X}} \mathrm{i}-0,60 \mathrm{SBi}\end{array}$ & $\begin{array}{l}1,80<X \\
\leq 2,60\end{array}$ \\
\hline Sangat & $\mathrm{X}<\overline{\mathrm{X}} \mathrm{i}-1,80 \mathrm{SBi}$ & $X \leq 1,80$ \\
\hline \multicolumn{3}{|c|}{$\begin{array}{l}\text { Keterangan: } \\
\mathrm{X}=\text { Skor yang diperoleh } \\
\overline{\mathrm{X}} \mathrm{i}=3 \\
\mathrm{SBi}=0,67 \\
\text { Sumber: Sukardjo }(2005: 53) \\
\text { dengan modifikasi }\end{array}$} \\
\hline
\end{tabular}

\section{HASIL PENELITIAN DAN PEMBA- HASAN \\ Deskripsi Data Penelitian}

Fokus penelitian ini adalah kelayakan media game edukatif "Asah Akuntansi" Subjek penelitian ini terdiri dari ahli materi (dosen Akuntansi Pajak), 1 ahli media (dosen Teknologi Informatika), 1 Praktisi Pembelajaran Akuntansi (Guru ekonomiAkuntansi), dan 27 siswa kelas XI IPS 3 SMA N 1 Imogiri. Data yang diperoleh kemudian disajikan dalam bentuk deskripsi. Deskripsi data yang disajikan dalam penelitian ini meliputi tabel penilaian dan diagram penilaian yang akan dibahas lebih lanjut pada bagian hasil penelitian dan pembahasan. 


\section{Hasil Penelitian}

Pengembangan game edukatif "Asah Akuntansi" berbasis android dilakukan melalui lima tahap yaitu:

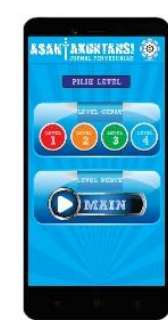

Memilih Leve
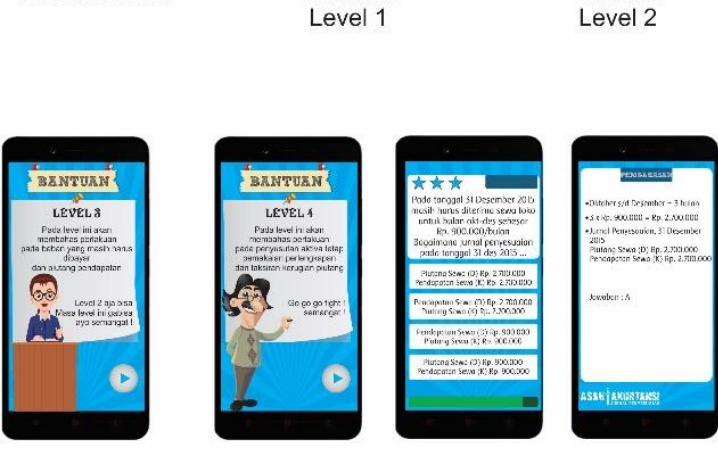

Bantuan Level 3

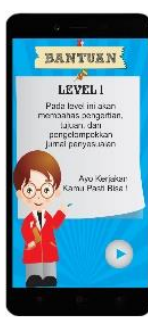

Bantuan Level 1

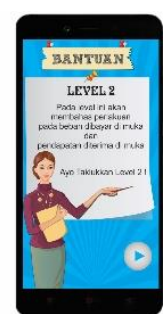

Bantuan Level 2

\section{Gambar 2. Story Board I}

1) Tahap Analisis (Analysis) berupa analisis kebutuhan berkaitan dengan permasalahan karakteristik siswa, perangkat keras (hardware) serta perangkat lunak (software) dan analisis kompetensi dan instruksional berkaitan dengan standar kompetensi dan kompetensi dasar yang akan dimuat dalam media.

2) Tahap Desain (Desain), merupakan tahap perancangan media yang meliputi pembuatan flowchart,storyboard, penyusunan materi, soal, dan jawaban, pengumpulan dan pembuatan background, gambar dan tombol, serta penggunaan musik dan suara.

3) Tahap Pengembangan (Development) berupa tahap pembuatan media pembelajaran asah akuntansi yang meliputi 4 kegiatan yaitu pembuatan antarmuka, pengkodean, pengujian, dan deploying, lalu validasi I, revisi I, validasi II, dan revisi II.

4) Tahap Implementasi (Implementation), meliputi tahap uji coba game edukatif "Asah Akuntansi" terhadap subjek uji coba lapangan. Berikut merupakan tampilan Media Pembelajaran game edukatif "Asah Akuntansi" berbasis android :
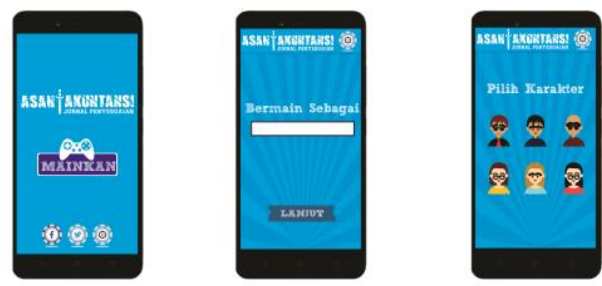

Halaman Awal

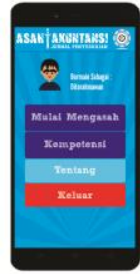

Halaman Utama

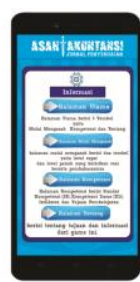

Informasi
Gambar 3. Story Board II 

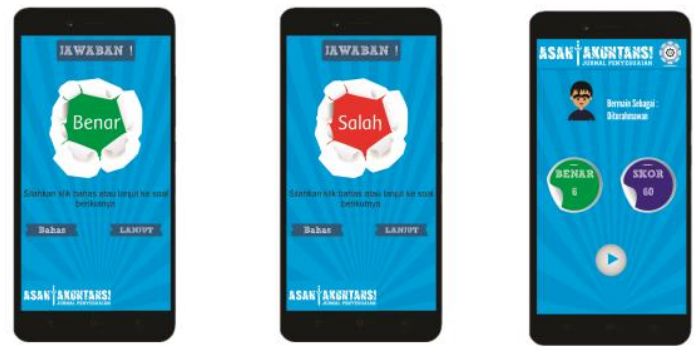

Konfirmasi Jawaban

Konfirmasi Jawaban Salah

Skor yang diperoleh
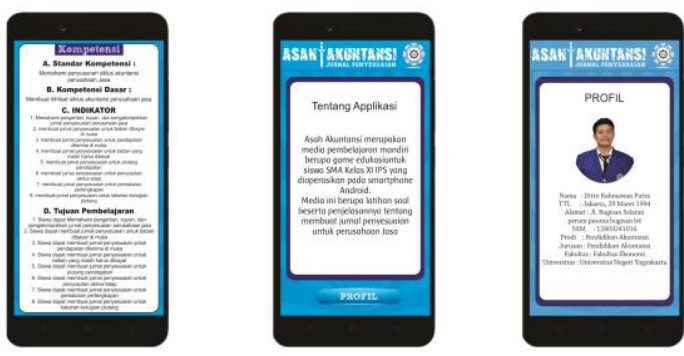

Kompetens

Tentang

Profil

\section{Gambar 4. Story Board III}

\section{Pembahasan}

a. Pengembangan Media Pembelajaran game edukatif "Asah Akuntansi" berbasis android

Pengembangan game edukatif "Asah Akuntansi" berbasis android mengikuti model pengembangan ADDIE, sesuai dengan teori yang dikemukakan oleh Dick dan Carry (1996) dalam Endang Mulyatiningsih (2012: 200-202) bahwa ada lima tahapan dalam model ADDIE yaitu tahap analisis (analysis), desain (design), pengembangan (development), implementasi (implementation), dan evaluasi (evaluation). Pertimbangan penggunaan model ini, karena model ADDIE sederhana dan terstruktur secara sistematis serta mudah dipelajari.

b. Kelayakan Media Pembelajaran Game Edukatif berbasis android "Asah Akuntansi" berdasarkan penilaian dari

ahli materi, ahli media,dan praktisi pembelajaran akuntansi.

Hal yang perlu diperhatikan ketika melakukan pengembangan suatu media adalah aspek kelayakan media itu sendiri. Kelayakan media pembelajaran diperoleh berdasarkan penilaian ahli materi (dosen Akuntansi Pajak), ahli media (dosen Teknologi Informatika), dan praktisi pembelajaran akuntansi (guru ekonomi-akuntansi) Berikut merupakan hasil validasi oleh ketiga ahli.

Tabel 3. Kelayakan Media pada Tahap Validasi

\begin{tabular}{|c|l|c|c|c|}
\hline $\begin{array}{c}\text { N } \\
\mathbf{0}\end{array}$ & \multicolumn{1}{|c|}{$\begin{array}{c}\text { Tahap } \\
\text { Penilaian }\end{array}$} & $\begin{array}{c}\text { Jum } \\
\text { lah } \\
\text { Skor }\end{array}$ & $\begin{array}{c}\text { Rera } \\
\text { ta } \\
\text { Skor }\end{array}$ & $\begin{array}{c}\text { Kelaya } \\
\text { kan }\end{array}$ \\
\hline 1 & $\begin{array}{l}\text { Penilaian Ahli } \\
\text { Materi }\end{array}$ & 72 & 4,87 & $\begin{array}{c}\text { Sangat } \\
\text { Layak }\end{array}$ \\
\hline 2 & $\begin{array}{l}\text { Penilaian Ahli } \\
\text { Media }\end{array}$ & 104 & 4,33 & $\begin{array}{l}\text { Sangat } \\
\text { Layak }\end{array}$ \\
\hline 3 & $\begin{array}{l}\text { Penilaian } \\
\text { Praktisi } \\
\text { Pembelajaran } \\
\text { Akuntansi }\end{array}$ & 109 & 4,75 & $\begin{array}{l}\text { Sangat } \\
\text { Layak }\end{array}$ \\
\hline \multicolumn{3}{|c|}{ Rata-rata } & $\mathbf{4 , 6 5}$ & $\begin{array}{l}\text { Sangat } \\
\text { Layak }\end{array}$ \\
\hline
\end{tabular}

Berdasarkan tabel 3 diketahui bahwa media pembelajaran "Asah Akuntansi" berbasis android memperoleh kategori Sangat Layak untuk tahap penilaian ahli materi dengan rerata skor 4,87 dan untuk tahap penilaian oleh Ahli Media memperoleh kategori Sangat Layak dengan rerata skor 4,33, kemudian untuk tahap penilaian oleh praktisi pembelajaran akuntansi memperoleh kategori Sangat Layak dengan rerata skor 4,75 dan secara keseluruhan dari ketiga tahap penilaian yang dilakukan oleh Ahli media, Ahli Materi, dan Praktisi Pembelajaran Akuntansi diperoleh rerata skor 4,65 yang masuk dalam kategori sangat layak. 
c. Kelayakan Media Pembelajaran Game Edukatif "Asah Akuntansi” berbasis android berdasarkan penilaian siswa.

Tabel 4. Penilaian Siswa Kelas XI IPS 3

\begin{tabular}{|c|c|c|c|c|}
\hline No & $\begin{array}{c}\text { Aspek } \\
\text { Penilaian }\end{array}$ & $\begin{array}{c}\text { Jumlah } \\
\text { Nilai }\end{array}$ & $\begin{array}{c}\text { Rata- } \\
\text { rata } \\
\text { Nilai }\end{array}$ & Kategori \\
\hline 1 & XI IPS 3 & 2261 & 4.19 & Layak \\
\hline \multicolumn{3}{|c|}{ Rata-rata } & $\mathbf{4 , 1 9}$ & Layak \\
\hline
\end{tabular}

Berdasarkan Tabel 4 diketahui bahwa penilaian siswa kelas XI IPS 3 terhadap media pembelajaran "Asah Akuntansi" berbasis android diperoleh rerata skor 4,19 yang masuk dalam kategori Layak.

Berdasarkan penilaian ahli materi, ahli media, praktisi pembelajaran akuntansi dan penilaian oleh siswa dapat disimpulkan bahwa game edukatif "Asah Akuntansi" berbasis android "Sangat Layak" digunakan sebagai media pembelajaran untuk siswa kelas XI IPS untuk mata pelajaran akuntansi, serta game edukatif ini dapat disebarluaskan sebagai salah satu alternatife media pembelajaran kepada siswa kelas XI IPS SMA di berbagai sekolah yang ada di Indonesia.

\section{SIMPULAN DAN SARAN}

\section{Simpulan}

Berdasarkan hasil penelitian dan pembahasan, dapat disimpulkan bahwa:

a. Pengembangan game edukatif "Asah Akuntansi" berbasis android pada materi jurnal penyesuaian melalui empat tahap yaitu : analysis, design, development, implementation.

b. Media pembelajaran game edukatif "Asah Akuntansi" berbasis android sangat layak digunakan sebagai media pembelajaran untuk siswa kelas XI IPS SMA Negeri 1 Imogiri.

\section{Saran}

Sebelum melakukan penelitian pengembangan, waktu pengembangan lebih diperhatikan khususnya dalam membuat media pembelajaran berbasis android. Serta game edukatif "Asah Akuntansi" ini perlu dikembangkan lebih lanjut seperti memuat animasi bergerak dan dapat digunakan di tablet android yang berukuran layar $\geq 7$ inchi sehingga tidak hanya digunakan dalam android.

\section{DAFTAR PUSTAKA}

Eko Putro Widoyoko. (2011). Evaluasi Program Pembelajaran. Yogyakarta: Pustaka Pelajar.

Eko Susanto. (2012). 60 Games untuk Mengajar. Yogyakarta: Lukita.

Endang Mulyatiningsih. (2012). Metode Penelitian Terapan Bidang Pendidikan. Bandung: Alfabeta

Nana Sudjana \& Ahmad Rivai. (2010). Media Pengajaran. Bandung: PT Sinar Baru Algesindo.

Sugiyono. (2013). Metode Penelitian Kuantitatif Kualitatif dan $R \& D$. Bandung: Alfabeta.

Sukardjo. (2005). Evaluasi Pembelajaran Semester 2. Yogyakarta: PPs UNY.

Tutut. (2013). Smartphone Android:Samsung Kuasai 80\% Pasar Indonesia.. Diakses tanggal 8 Desember 2015 dari http://www.solopos.com/2013/08/01/p enjualan-smartphone-samsungkuasai80-pasar-indonesia-433539. 